\title{
Improving children's language skills through online learning during covid-19 pandemic
}

\author{
Robingatin, Wildan Saugi, Susan \\ Institut Agama Islam Negeri Samarinda, Indonesia \\ e-mail: robingatin.ms01@gmail.com
}

\section{Article History}

Submitted: November 18, 2020

Accepted: January 16, 2021

Published: February 16, 2021

DOI:10.26555/jecce.v3i2.2246
Abstract

The present study was done to find out the children's language skill improvement in online learning during Covid-19 pandemic at TK IT Bunga Harapan. In order to maintain children's language development amid the pandemic, online learning was implemented. Qualitative approach was applied. We involved 12 preschool students as the participants of the study. The data were collected through observation, interview, and documentation. Children's language skill improvement in TK Bunga Harapan was proven by the decrease in number of students suffering from speech delay, from 4 students (25\%) to 1 student (6.25\%) out of 12 students. This improvement was noticed after teachers conducted online learning activities that provided children with experience to make videos stimulating them to communicate and speak. With regard to the assessment, teachers used anecdotal notes by observing the children's development through videos they made.

Keywords : Online Learning, Language Skills, Covid - 19.

\section{Abstrak}

Penelitian ini dilaksanakan untuk mengetahui peningkatan kemampuan bahasa anak pada pembelajaran online di masa pandemi Covid-19 di TK IT Bunga Harapan Samarinda. Salah satu alternatif pembelajaran yang dapat dilaksanakan untuk tetap meningkatkan aspek perkembangan bahasa anak yakni melalui pembelajaran online. Penelitian ini menggunakan pendekatan kualitatif. Subjek penelitian yaitu 12 siswa TK IT Bunga Harapan. Teknik pengumpulan data menggunakan observasi, wawancara, dan dokumentasi. Peningkatan kemampuan berbahasa pada siswa di TK Bunga Harapan ditunjukkan dengan turunnya persentase keterlambatan berbicara (speech delays) dari 4 anak (25\%) menjadi 1 anak (6,25\%) dari 12 anak. Peningkatan ini terjadi setelah proses pembelajaran online yang memberikan anak pengalaman untuk membuat video sehingga memacu anak untuk berkomunikasi dan berbicara. Bentuk penilaian untuk mengetahui peningkatan berbahasa anak adalah melalui catatan anekdot yakni dengan cara melihat perkembangan anak dari hasil video yang anak buat.

Kata Kunci : Pembelajaran Online, Kemampuan Bahasa, Covid - 19. 


\section{INTRODUCTION}

Early childhood education is pivotal for children (Rasyid, 2015). As stated in Indonesian Minister of Education and Culture Regulation (Hereafter Permendikbud) No 137 and No. 146 of 2014 concerning Early Childhood Education Curriculum, early childhood education is pivotal for children because their development in the next phase is determined by stimulus they received during preschool age (Kemdikbud, 2015). Therefore, attention from the government, education practitioners, parents, and teachers are important. Considering this importance, Indonesian government has made an effort to provide a child-friendly education process by enacting Law no. 20 of 2003 on National Education System. Article 1 paragraph 1 of that Law stipulates that education should be organized by considering every aspect in order to create an enjoyable learning atmosphere to optimize students' potential and ability (Mulyasa, 2012).

Providing a supportive learning atmosphere is challenging, especially during the Covid19 pandemic. This pandemic changes many life aspects due to rapid, massive viral spread. In Indonesia, the virus forces Indonesian education, from Early childhood education to University level, to shift to distance learning (PSSAT, 2020).

Circular Letter issued by Indonesian Ministry of Education and Culture (Kemendikbud) no. 4 of 2020 on The Implementation of Education Policy during COVID-19 pandemic states that the teaching and learning process is carried out from home. It was done to make sure that the education process keeps running despite the pandemic situation. To cope with the viral spread, the learning process is carried out through digital devices (Kemdikbud, 2020). The massive spread of Covid-19 forces the Indonesian Ministry of Education to move the teaching and learning process into online setting. Moore, Dickson-Deane, \& Galyen, as cited in (Firman \& Rahayu, 2020), define online learning as a learning activity that utilizes internet access that provides accessibility, connectivity, flexibility to present a range of learning interactions. During Covid-19 pandemic, online learning is viewed as an alternative to support the education process, especially at ECE level. Considering advantages the online learning provides, pandemic situation supposes to be a trigger for teacher's innovation rather than solely a hindrance to learning process.

Our observation showed that ECE institution, especially TK IT Bunga Harapan Samarinda, has implemented online learning process. Online learning is different from conventional ones since this learning allows students and teachers to get involved in learning process through a virtual classroom although they do not physically meet. Learning activity is a 
process where a child is involved in an academic process in order to obtain new knowledge and experience (Mursid, 2015). Since the Learning process may influence children's attitude and behavior, their involvement in learning process may affect their persistence, attention, passion, and autonomy (Mursid, 2015).

Online learning at the ECE level should pay attention to children's developmental aspects. Fakhruddin argues that the preschool period is the golden age that should be optimized through the provision of special attention and treatment. Teacher's roles are fundamentals because children's growth and development are significantly affected by their touch and thoughts. Our observation showed that online learning was carried out through a number of applications, including WhatsApp and Zoom Cloud Meeting. Online learning requires children to be able and willing to speak, although they were helped by their parents during the process.

Our interview with the principal revealed that some children suffered from speech delay. It possibly occurs because children lack of stimulus (Fitriyani et al., 2019; Hutami \& Samsidar, 2018). Some students had not been able to pronounce words clearly, i.e., pronouncing ustadzah as zah. In addition, it was also found that some children can only communicate using non-verbal language (e.g., nodding, shaking head, or pointing the object) without pronouncing what they want. If they could not get what they want, they will show their anger through crying. During the learning process, they tend to be silent and not interacting with their friends. The interview revealed that out of 12 children, four of them suffered from speech delay.

Language skill is a result of combination of all developmental system of a child. A Child's language development is sensitive to damage in other systems. In this regard, a child's language skill involves motor, emotional, social, and cognitive aspects. In other words, language development is children's progress where they try to understand what they want to tell to others (Mulyani, 2018). Language development plays pivotal role for human life, especially for preschool-aged children because language is a means for children to express their thought and feeling to other people (Astuti \& Habibah, 2015; Wahyudin \& Agustin, 2011). A number of aspects of children's language development should be taken into account to adjust them to children's developmental stage. These aspects include listening, speaking, writing, and reading skills. Following preschool-aged children's characteristic, listening and speaking skills are the main aspects a child should develop first (Pebriana, 2017). 
Grounded on the description above, the study focused on the improvement of children's language skill. This is interesting because during Covid-19 pandemic, the effort to improve children's language skills is done in online setting.

\section{METHOD}

Applying qualitative descriptive approach, this study aimed to describe the online learning process that was carried out to improve children's language skills during the Covid-19 pandemic. This study took place in TK IT Bunga Harapan Samarinda. Twelve students from this institution were involved, their age ranged from 4-5 years old. The data were collected through observation, interviews, and documentation. We observed the online learning process that had been designed through teachers' lesson plans. Teachers sent a video to the students according to the predetermined theme and at the end of the process, the students were asked to create their own video to be assessed by the teachers. With their parents' help, students were asked to create a video and sent it to the teachers. The video was then assessed by the teachers to see the students' language development. Some indicators were used, including: (1) Listening and giving appropriate responses; (2) speaking confidently; and (3) using language to obtain information to communicate and interact effectively (Depdiknas, 2007; Kemdikbud, 2015).

This participatory observation allowed us to directly involve in the participant's activities. Once the observation ended, interviews related to the online learning process were conducted. Interviews were done with the principal, teachers, and parents. These interviews allowed us to gain more in-depth data related to the participants and the situation. We also documented the online learning process, including teachers' videos, students' videos, and lesson plans. Documentation is defined as a note of an event that can be in the form of script or pictures (Sugiyono, 2015).

\section{RESULT AND DISCUSSION}

Today's technology allows us to perform online learning activities. It emerges as a result of innovation. One of the results of this innovation is gadget. Almost all people from any social level and age use gadget and access the internet in their daily life (Novianti \& Garzia, 2020). Novitasari argues that, through their gadget, people make social interaction with others easily . Gadget is a small devices with useful practical functions (Pebriana, 2017) 
Our observation revealed that some learning plans were postponed due to Covid-19 pandemic. However, the principal and the teachers attempted to implement the designed lesson plan in through e-learning process. E-learning refers to a learning method that allows teaching and learning process to be done through the internet or other computer networks. E-learning allows various types of interaction, such as chatting or watching recorded learning materials through website. Some applications are developed to support e-learning, such as, among others, Quipper School, Edmodo, and Google Classroom (Ridoh et al., 2020).

During Covid-10 pandemic, e-learning is implemented to keep the learning process running. In addition to the learning media mentioned above, people also use Whatsapp to carry out the online learning process. This application was also used as a learning media in TK IT Bunga Harapan. In its process, teachers and students sent their learning video through WhatsApp. TKIT Bunga Harapan also used Zoom Cloud Meeting that allows all students to interact at the same time.

The principal and teachers had also prepared study from home activities, which includes habituation. The habituation includes, among others, 7-steps handwashing, wudu, and, duha prayer. In online learning, habituation is inseparable from the parents' role (Dahlia, personal Communication, 2020) because, as (Mohammadi et al., 2017) argue, family may significantly affects children's academic achievement and self-confidence. Diadha, as cited in (Ardiyana et al., 2019), argues that parents play important role in preschool-aged children's development.

Children's development could be optimal if it is supported by the synergy of teachers and parents' role (Diadha, 2015). During the pandemic, parent's roles are pivotal in online learning process. One of the parents' roles in online learning process is to assist and motivate their children during the process (Lilawati, 2020). The parents' and teachers' role during online learning includes facilitating, accompanying, motivating, supporting, and documenting children's development. In addition to analyzing children's developmental progress, teachers should also help parents to arrange children's daily activity in order to make sure that their activities support their developmental progress (Yuliantina, 2020). Teachers' roles also include, among others, preparing the learning materials, preparing tools and materials to provide examples for children to be followed from home. Teachers also made a learning video and sent it to the students. The students were asked to learn from that video. They watched, understood, and practice the play presented by the teacher through video. 
Arsiah states that online learning demands teachers' creativity since it is different from offline learning (Arsiah, Personal Communication, 2020). Arsiah further argues that the online learning process is carried out by providing learning videos according to the theme and instructions. The video was sent through Whatsapp. Students were obliged to send their work every day at any time. In other words, there was no deadline for submitting their work. Children's mother was often involved during the online learning process.

\section{Enhancing Children's Language Skill during Covid-19 Pandemic}

Some adjustments should be made to make sure that the learning process can be done during this pandemic. One of the adjustments is that teachers should still used storytelling method during the video-making process. As (Hemah et al., 2018) state, storytelling could increase children's language skill. Language is a tool of communication that is used since an individual is born. Its acquisition begins when a child receives his/her first language (Hertini, 2010).

Children's language development aspects include listening, speaking, reading, and speaking skills (Khotijah, 2016). During the online learning process, children were directed to speak. Speaking helps children to develop their language skills (Muliawati et al., 2019). Speaking is an activity to express one's thought and feelings toward his or her interlocutor. This activity involves three processes, namely pronunciation, building vocabulary, and making a sentence (Lestari et al., 2017).

In this study, language development aspects are similar to those in (Hemah et al., 2018; Khotijah, 2016; Lestari et al., 2017; Muliawati et al., 2019)'s study, namely children's ability to pronounce a word. However, our study is different from previous study where teachers and students were only involved in online interaction. Although it was not face-to-face interaction, children were still able to learn to pronounce words and make sentences. Children were asked to make a video. By making a video, children were indirectly stimulated to speak. In general, these listening and speaking activities allowed children to be able to: (1) Listening and giving appropriate responses; (2) speaking confidently; and (3) using language to obtain information to communicate and interact effectively (Depdiknas, 2007).

Children's language skills vary, depending on their developmental progress. They use language to communicate and interact with other people, such as parents and friends. Our study found that some children found it difficult to understand the teacher's story, express their 
thought, or even speak in front of the class. A specified learning method is necessary to stimulate their language skills.

Since students were asked to make a video, They were able to speak and communicate in front of the camera. This was proven to improve their language skill. During the process, some children were assisted by their parents, while others were not. According to Dahlia, during the process, the number of students who suffered from speech delay was decreased from 4 to 1 . (Dahlia, Personal Communication, 2020).

Dahlia stated that in order to improve the students' language skills during Covid-19 pandemic, students were asked to tell about their daily activities after watching the video the teachers sent. One of the videos showed how children spoke about the process of ice. In this process, it could be noticed how children's language skills were improved when they tell about the process. This was one of the methods applied by the teachers to improve the students' language skills (Dahlia, Personal Communication, 2020).

Permendiknas no. 137 of 2017 on Early Childhood Education National Standard stipulate that 4-5 years old children shall be able to receive and express language. Regarding receptive skills, children at this age have been able to listen to other people, understand two instructions, understanding a story, and recognize adjectives. Meanwhile, regarding productive skills, preschool-aged children have been able to repeat simple sentences, express their feelings, mention words they have known, express their idea, state reasons, and retell what they know or hear. With regard to vocabulary, 4-5 years old children have been able to recognize symbols, various sounds, making scratch, and imitate letters (Kemdikbud, 2015).

According to Arsiah, online learning is not optimal for children's development, compared to face-to-face interactions. However, considering the language development described in the Early Childhood Development Achievement Standard, as stipulated in Permendikbud $137 / 2014$, it could be concluded that children's language skills were improved. This improvement was shown by their ability to communicate and speak naturally, e.g., pronouncing words, building vocabulary, and making sentences (Arsiah, Personal Communication, 2020). This is consistent with a study conducted by (Setyawan, 2016) who found that a video may improve children's language skill since it stimulates children's intellectual and emotional involvement that makes children enjoy the learning process.

In line with Dahlia, Arsiah also stated that by watching the children's video made, teachers could see the children's language skill improvement. This improvement was shown 
when children tell their feelings when they were at home. With regard to assessment of online learning, Arsiah explained that it was done by using anecdotal notes.

\section{CONCLUSION}

The present study shows that online learning activities can improve children's language skill. Children are naturally stimulated to speak through videos they made. In this study, WhatsApp and Zoom Cloud Meeting were used as the main media during th learning process. The improvement could be seen from the number of children suffering speech delay, which decreased from 4 children to 1 children.

\section{REFERENCES}

Ardiyana, R. D., Akbar, Z., \& Karnadi, K. (2019). Pengaruh Keterlibatan Orang Tua dan Motivasi Intrinsik dengan Kepercayaan Diri Anak Usia Dini. Jurnal Obsesi : Jurnal Pendidikan Anak Usia Dini, 3(2), 494-505. https://doi.org/10.31004/obsesi.v3i2.253

Astuti, W., \& Habibah, U. (2015). Peningkatan Kemampuan Kosakata Bahasa Inggris Anak Melalui Metode Pembelajaran Interaktif di Kelompok A TK Pertiwi I Jirapan 2014/2015. http://publikasiilmiah.ums.ac.id/handle/11617/6030

Depdiknas. (2007). Pedoman Pembelajaran Bidang Pengembangan Berbahasa di Taman Kanak - Kanak.

Diadha, R. (2015). Keterlibatan Orang Tua Dalam Pendidikan Anak Usia Dini Di Taman KanakKanak. Edusentris, 2(1), 61-71. https://doi.org/10.17509/edusentris.v2i1.161

Firman, F., \& Rahayu, S. (2020). Pembelajaran Online di Tengah Pandemi Covid-19. Indonesian Journal of Educational Science (IJES), 2(2), 81-89. https://doi.org/10.31605/ijes.v2i2.659

Fitriyani, F., Sumantri, M. S., \& Supena, A. (2019). Language development and social emotions in children with speech delay: Case study of 9 year olds in elementary school. Jurnal Konseling Dan Pendidikan, オ1), 23-29. https://doi.org/10.29210/130600

Hemah, E., Sayekti, T., \& Atikah, C. (2018). Meningkatkan Kemampuan Bahasa Anak Melalui Metode Bercerita Pada Anak Usia 5-6 Tahun. Jurnal Penelitian Dan Pengembangan Pendidikan Anak Usia Dini, 5(1), 1-14. https://doi.org/10.30870/jpppaud.v5i1.4675 
Hertini, E. (2010). Bahasa dan Kelahirannya. Adabiyyat : Jurnal Bahasa Dan Sastra, 910), 107132. https://doi.org/10.14421/ajbs.2010.09106

Hutami, E. P., \& Samsidar. (2018). Strategi Komunikasi Simbolik Speech Delay Pada Anak Usia 6 Tahun di TK Paramata Bunda Palopo. Jurnal Tunas Cendikia : Jurnal Program Studi $\begin{array}{llll}\text { Pendidikan Anak Islam, 39-43. } & \text { 1(1), }\end{array}$ https://doi.org/10.24256/tunas\%20cendekia.v1i1.384

Kemdikbud. (2015). Permendikbud 137 tahun 2014 Standar Nasional PAUD.

Kemdikbud. (2020). Sikapi COVID-19, Kemendikbud Terbitkan Dua Surat Edaran. Www.Kemdikbud.Go.Id. https://www.kemdikbud.go.id/main/blog/2020/03/sikapicovid19-kemendikbud-terbitkan-dua-surat-edaran

Khotijah. (2016). Strategi Pengembangan Bahasa pada Anak Usia Dini. Elementary : Jurnal IImiah Peniddikan Dasar, 2(2), 35-44.

Lestari, V. U., Saparahayuningsih, S., \& Yulidensi. (2017). Meningkatan Keterampilan Berbicara dengan Bercerita melalui Media Audio Visual VCD pada Anak Kelompok B PAUD Dharma Wanita Kabupaten Bengkulu Tengah. Jurnal IImiah Potensia, 2(2), 139-146. https://doi.org/10.33369/jip.2.2.139-146

Lilawati, A. (2020). Peran Orang Tua dalam Mendukung Kegiatan Pembelajaran di Rumah pada Masa Pandemi. Jurnal Obsesi : Jurnal Pendidikan Anak Usia Dini, 5(1), 549-558. https://doi.org/10.31004/obsesi.v5i1.630

Mohammadi, Y., Moqaddam, K. A., Ganjifard, M., \& Kazemi, S. (2017). The Relationship of Parenting Styles, Self-confidence and Students' Academic Achievement. Future of Medical Education Journal, 73), 9-13. https://doi.org/10.22038/fmej.2017.24098.1149

Muliawati, A., Sumardi, \& Elan. (2019). Meningkatkan Kemampuan Berbicara Anak Melalui Metode Bercerita dengan Menggunakan Boneka Tangan pada Kelompok B di TK Plus Salsabil Kabupaten Cirebon. Jurnal Paud: AGAPEDIA, 3(1), 11-23. https://doi.org/10.17509/jpa.v3i1.26664

Mulyani, N. (2018). Perkembangan Dasar Anak Usia Dini. Penerbit Gava Media.

Mulyasa. (2012). Manajemen PAUD. Remaja Rosdakarya.

Mursid. (2015). Belajar dan Pembelajaran PAUD(1st ed.). Remaja Rosdakarya. 
Novianti, R., \& Garzia, M. (2020). Penggunaan Gadget pada Anak; Tantangan Baru Orang Tua Milenial. Jurnal Obsesi : Jurnal Pendidikan Anak Usia Dini, 4(2), 1000-1010. https://doi.org/10.31004/obsesi.v4i2.490

Pebriana, P. H. (2017). Analisis Kemampuan Berbahasa dan Penanaman Moral pada Anak Usia Dini melalui Metode Mendongeng. Jurnal Obsesi : Jurnal Pendidikan Anak Usia Dini, 1(2), 139-147. https://doi.org/10.31004/obsesi.v1i2.25

PSSAT. (2020). Covid-19: Wajah Pendidikan Singapura dan Indonesia. Pusat Studi Sosial Asia Tenggara Universitas Gajah Mada (PSSATUGM). https://pssat.ugm.ac.id/id/covid-19wajah-pendidikan-singapura-dan-indonesia/

Rasyid, H. (2015). Membangun Generasi Melalui Pendidikan Sebagai Investasi Masa Depan. Jurnal Pendidikan Anak, 4(1), 565-581. https://doi.org/10.21831/jpa.v4i1.12345

Ridoh, A., Putra, Y. I., \& Huda, F. (2020). Pengembangan Media Pembelajaran E-Learning Berbasis Web Pada Mata Pelajaran Sistem Operasi Kelas X SMK Adzkia Padang. Jurnal Inovasi Pendidikan Dan Teknologi Informasi, 1(1), 32-41.

Setyawan, F. H. (2016). Meningkatkan Kemampuan Berbahasa Anak Usia Dini Melalui Model Pembelajaran Audio Visual Berbasis Android. Jurnal PG-PAUD Trunojoyo, 3(2), 1-75. https://doi.org/10.21107/pgpaudtrunojoyo.v3i2.3490

Sugiyono. (2015). Metode Penelitian Pendidikan Pendekatan Kantitatif, Kualitatif, dan R\&D. Alfabeta.

Wahyudin, U., \& Agustin, M. (2011). Penilaian Perkembangan Anak Usia Dini. Refika Aditama.

Yuliantina, I. (2020). Implementasi Belajar di Rumah (Perencanaan, Pelaksanaan dan Penilaian). STKIP Panca Sakti, Bekasi. 